\title{
Is clear cell carcinoma of abdominal wall surgery scar associated with endometriosis a poor prognosis? A case report and literature review
}

\author{
Xuzhi Liang \\ Guangxi Medical University First Affiliated Hospital \\ Hao Zeng \\ Guangxi Medical University First Affiliated Hospital \\ Zhe Tang \\ Guangxi Medical University First Affiliated Hospital \\ Jiejie Liao \\ Guangxi Medical University First Affiliated Hospital \\ Jiangtao Fan ( $\sim$ JT_fan2018@163.com ) \\ Guangxi Medical University https://orcid.org/0000-0003-1308-4533
}

\section{Case report}

Keywords: clear cell carcinoma, abdominal wall surgery scar, chemotherapy, prognosis

Posted Date: January 19th, 2021

DOI: https://doi.org/10.21203/rs.3.rs-146993/v1

License: (c) (i) This work is licensed under a Creative Commons Attribution 4.0 International License. Read Full License 


\section{Abstract}

Background

Clear cell carcinoma of abdominal wall surgery scar is a rare condition that can have many potential causes, and its early diagnosis is difficult after undergoing obstetrical and gynecological surgery unless performing tumor biopsy. So far, about 45 cases have been reported in the literature. This paper provides a case report and literature review of clear cell carcinoma on abdominal wall surgical scar.

\section{Case presentation}

We described the case of a 47-year-old woman reporting two lumps in the scar of abdomen. Her medical history was marked by a previous Caesarean section and two excisions of benign endometriosis nodules at the scar. Physical examination found a mass of about $6 \times 5 \times 5 \mathrm{~cm}$ on the left side of the scar with mucoid on the surface and a fixed abdominal wall mass of about $10 \times 10 \times 8 \mathrm{~cm}$ in the 2 transverse fingers under the umbilicus. Histological examination proved a clear cell carcinoma result. The patient received tumor excision and first-line chemotherapy with complete remission. A review of the literature showed that $91.3 \%$ of the cases had had a Caesarean section. Besides, approximately $34.2 \%$ of women died $5-48$ months after diagnosis. The average age of women was 46.5 years and the average tumor size was $10 \mathrm{~cm}$.

\section{Conclusion}

The abdominal wall mass of middle-aged women is closely related to the scar left by the previous Cesarean section and must be investigated in time and properly. Preoperative diagnosis is difficult and often incorrect, and there is no specific marker for malignant transformation. Treatment usually includes surgery, chemotherapy, and radiotherapy, but the prognosis is poor.

\section{Background}

The incidence of scar endometriosis in abdominal surgery is between $0.03 \%$ and $1.08 \%$ in women undergoing pelvic surgery [1, 2]. Abdominal wall endometriosis caused by incisions is an often neglected disease [3]. Scar endometriosis is usually caused by the implantation of endometrial tissue into the soft tissue of the abdominal wall during surgery. Symptoms of endometriosis in abdominal surgical scars in obstetrics and gynecology include slowly developing lumps in or near the scar, as well as pain and abdominal swelling during menstruation. However, malignant transformation of abdominal wall endometriosis is very rare, including sarcomatoid degeneration [4], serous papillary carcinoma [5, 6], rhabdomyosarcoma [7] as well as clear cell carcinoma (CCC). The most common histological type is CCC [8]. CCC caused by endometriosis is an invasive disease with a poor prognosis, with a 5 -year survival rate of about $40 \%$ [8]. Diagnosis is challenging because the disease develops slowly and has no specific markers of malignant transformation.

Here we report a patient with CCC of the abdominal wall at the scar site of a previous Cesarean section (CS). Besides, we reviewed the existing English literature on transparent clear cell carcinoma caused by endometriosis in the abdominal wall and compared the clinical features of abdominal wall masses of different sizes.

\section{Case Presentation}

A 47-year-old woman, grava 4, para 3, abortion 1, presented with two big abdominal masses, which were gradually enlarging after 2 previous excisions of an endometriotic nodule in a CS scar. This patient underwent a CS in 2001 due to fetal distress and transverse position. The CS procedure was successful, with no postoperative discomfort such as abdominal pain, abdominal distension, and the menstruation is regular. Early in 2017 , she noticed a small mass of about $1 \mathrm{~cm}$ in right lower abdominal scar without menstrual period pain and itching. She underwent abdominal endometriosis mass resection in May 2017. During the operation, the boundary between the mass and abdominal wall tissue was not clear, and a mesh was placed to repair the abdominal wall. The mass containing chocolate-like fluid with a hard texture. The pathology of the nodule was reported as endometriosis with decidual degeneration. The mass in the abdominal wall is consistent with the adenomatoid tumor. Microscopically, a large amount of dilated cystic cavity was seen in the fibrous tissue, which was lined with a single layer of epithelium, which was flat or cuboidal cells, and interstitial mucus degeneration. Immunohistochemical stains included CKp (+), CK7 (+), ER (+), PR (-), CK (5/6), CR (+/-), D2-40 (+/-), CD34 (-), Ki-67-LI (10\%).

At the beginning of 2018, the patient again realized that she could touch the mass in the right lower abdominal scar, which was about $3 \mathrm{~cm}$ in size. During exercise, the lower abdomen occasionally felt slight pain, relieved with rest, and had nothing to do with the menstrual cycle. The abdominal mass gradually increased. In November 2019, she underwent excision of abdominal wall endometriosis and mesh repair because of abdominal wall mass. Postoperative pathology showed that endometriosis with deciduous degeneration. She was then given a subcutaneous injection of Leuprorelin for the purpose of preventing recurrence. However, the size of the right lower abdominal mass remained enlarged, and a similar painless mass, about $2 \times 1 \times 1 \mathrm{~cm}$, was also found in the scar of the left lower abdominal CS in April 2020. She didn't experience any pain at the scar during menstruation. She did not visit a doctor until the mass gradually enlarged and protruded the abdominal epidermis with broken ulcer and mucous bloody secretions in September 2020. She was then referred to our hospital for further management. At this time, physical examination revealed a $12 \mathrm{~cm}$ transverse shape of the CS scar of the lower abdomen. A purplish-black mass of about $6 \times 5 \times 5 \mathrm{~cm}$ can be seen on the left side of the scar with mucoid on the surface. A hard mass of about $10 \times 10 \times 8 \mathrm{~cm}$ can be palpated in the 2 transverse fingers under the umbilicus. Pelvic examination showed a normal-sized uterus 
and lateral adnexa. A biopsy from the mass in combination of immunohistochemical examination confirmed a pathology of endometriosis-associated CCC.

The preoperative pelvic magnetic resonance imaging (MRI) showed that the parenchyma of the tumor showed equal T1 and long T2 signal intensity, with a clear boundary, and the larger one was $6.2 \times 3.6 \times 4.2 \mathrm{~cm}$ (Fig. 1A-C). No obvious enhancement was found on contrast-enhanced scan after injection of contrast agent. There was no abnormality in the uterus, bilateral adnexa, and no enlarged lymph nodes in the pelvis. Ultrasound scan showed normal liver, spleen, pancreas, kidneys, and no mass in the abdominal cavity. Hence, a multidisciplinary team including dermatology, gynecologic oncology, gastrointestinal glandular surgery, and plastic surgery department made a treatment plan for the patient preoperatively. During operation, gross complete excision with a surgical margin of $1 \mathrm{~cm}$ beyond the lesion of the abdominal wall including the rectus abdominis muscle, together with an abdominal wall reconstruction was performed (Fig. 2A-C, Fig. 3A, Fig. 4A and B). It can be seen that the tumor infiltrated part of the fascia and rectus abdominal tissue, the bottom of the tumor reached the peritoneum and protruded to the abdominal cavity, and part of the omentum majus, intestine adhered to the peritoneum. No abnormality was found in the uterus and bilateral adnex, omentum and intestine. The pelvic lymph nodes were not enlarged. After separating the abdominal wall mass, the defect of fascia, rectus abdominis, and peritoneum on the right side of the wound could be seen, with an area of $15 \times 13 \mathrm{~cm}$. Considering the large defect of rectus abdominis and peritoneum, mesh repair was performed (Fig. 3B.C). Hysterectomy and bilateral salpingo-oophorectomy were not performed. The operation time was 300 minutes, of which 160 minutes were resected and $140 \mathrm{~min}$ was reconstructed. There were no intraoperative complications. The blood loss was estimated to be $200 \mathrm{~mL}$. Pathologic examination of resected abdominal wall lesion showed CCC under the background of endometriosis with clear resection margins (Fig. 5). The patient was referred to plastic surgery for further care due to the huge surgical wound for 18 days. Chemotherapy with paclitaxel liposome and carboplatin regimen was conducted on day 19 and she was discharged on postoperative day 20. A month later, she returned to the hospital on time for chemotherapy, with no signs of recurrence. She is still closely followed up during the preparation of the manuscript.

\section{Discussion}

The diagnosis of malignant transformation of abdominal endometriosis is still a challenge for gynecologists. There are no characteristic symptoms and markers in the process of carcinogenesis. The best treatment for malignant transformation of abdominal endometriosis is not clear. We searched the articles published from September 1986 to December 2020 by Medline and EMBASE, and the search words were combined into medical subject entries. The keywords used for the search are as follows: "abdominal wall endometriosis" and "clear cell carcinoma". All relevant articles were retrieved and the list of relevant references was systematically reviewed to determine further reports that could be included in this analysis. Besides, reviews of cancer and endometriosis published over the same period were reviewed and their reference lists were searched for potential additional studies. We used SPSS 23.0 statistical software for statistical analysis. The unpaired t-test of continuous variables and the chi-square test of classified variables were used in the comparison between groups. GraphPad's Kaplan-Meier estimation was used for survival analysis.

Finally, we included 45 patients in our systematic retrospective analysis, including 44 from the literature review and 1 from our organization. All of them reported that endometriosis was associated with malignant transformation of the surgical scar. The characteristics of the patients are shown in Table 1. As shown in Fig. 6, it is more common than previously reported, especially if we consider the increasing rate of CS in western countries [9]. The average age of the patients at the time of diagnosis was 46.5 years (range from 37 to 60), which was consistent with the retrospective analysis of Endometriosis-associated malignant transformation in an abdominal surgical scar by Mihailovici et al. [8]. Fifteen cases (33.3\%) had a history of endometriosis and 28 cases (62.2\%) had never been diagnosed with endometriosis before admission ( 2 cases were not clear). The average delay from the first operation to diagnosis was 17.9 years (standard deviation 6.6). CCC is related to uterine surgery, mainly the CS. Forty-two cases (91.1\%) had at least one CS, of which 15 cases had 2 CS s, 6 cases had 3 CSs, and 4 cases (8.9\%) had undergone other gynecological operations, usually CS (Table 2). At least one excision of scar endometriosis was performed in 9 cases, including our case. 
Table 1

Summary of studies included in the review.

\begin{tabular}{|c|c|c|c|c|c|c|c|c|c|c|c|}
\hline \multirow[t]{2}{*}{ Author } & \multirow[t]{2}{*}{ Year } & \multirow[t]{2}{*}{ Age } & \multirow{2}{*}{$\begin{array}{l}\text { Delay from } \\
\text { first } \\
\text { gynecological } \\
\text { surgery(yr) }\end{array}$} & \multirow{2}{*}{$\begin{array}{l}\text { Onset of } \\
\text { symptoms(m) }\end{array}$} & \multirow{2}{*}{$\begin{array}{l}\text { Lump } \\
\text { size(cm) }\end{array}$} & \multirow[t]{2}{*}{ Surgery } & \multirow[t]{2}{*}{ Pathology } & \multicolumn{4}{|c|}{ Patient outcome } \\
\hline & & & & & & & & $\begin{array}{l}\text { Follow- } \\
\text { up } \\
\text { time } \\
\text { (m) }\end{array}$ & Relapse & $\begin{array}{l}\text { Follow- } \\
\text { up } \\
\text { time } \\
\text { (m) }\end{array}$ & Death \\
\hline Giannella [15] & 2020 & 45 & 15 & 3 & 20 & no & $\mathrm{CCC}$ & NA & yes & 7 & yes \\
\hline Behbehani[20] & 2019 & 48 & NA & 5 & 7 & yes & $\mathrm{CCC}$ & NA & NA & NA & NA \\
\hline Tsuruga [12] & 2019 & 49 & 15 & 3 & 5 & yes & $\mathrm{CCC}+\mathrm{EC}$ & 4.5 & no & NA & NA \\
\hline Rivera [19] & 2019 & 48 & NA & NA & 7 & yes & $\mathrm{CCC}$ & 2 & no & NA & NA \\
\hline Lopes [10] & 2019 & 48 & 12 & 84 & 12 & yes & $\mathrm{CCC}$ & 3 & no & NA & NA \\
\hline Lai [23] & 2019 & 56 & NA & 396 & 6.5 & yes & $\mathrm{CCC}$ & 3 & $\begin{array}{l}\text { yes, } \\
\text { Inguinal } \\
\text { LN }\end{array}$ & 11 & yes \\
\hline Lai [23] & 2019 & 56 & NA & 252 & 12 & yes & $\mathrm{CCC}$ & NA & NA & 5 & yes \\
\hline Lai [23] & 2019 & 45 & NA & 240 & 4.8 & no & $\mathrm{CCC}$ & 7 & $\begin{array}{l}\text { yes, Abd. } \\
\text { wall, } \\
\text { inguinal } \\
\text { LN }\end{array}$ & 7 & yes \\
\hline Gentile[26] & 2018 & 42 & 7 & 8 & 10.6 & yes & $\mathrm{CCC}$ & 2 & no & NA & NA \\
\hline Mihailovici [8] & 2017 & 47 & 22 & 264 & 11 & yes & $\mathrm{CCC}$ & NA & NA & NA & NA \\
\hline Wei [24] & 2017 & 46 & 18 & 2 & 9.5 & yes & CCC & 3 & no & NA & NA \\
\hline Marques [27] & 2017 & 47 & 24 & 3 & 8 & yes & CCC & 45 & no & NA & NA \\
\hline Kostrzeba [28] & 2017 & 58 & 38 & NA & 25 & yes & $\mathrm{CCC}$ & 3 & no & NA & NA \\
\hline Graur[29] & 2017 & 43 & 22 & 7 & 8.5 & yes & $\mathrm{CCC}$ & 11 & no & NA & NA \\
\hline $\begin{array}{l}\text { Ferrandina } \\
\text { [16] }\end{array}$ & 2016 & 44 & 9 & 8 & 22 & yes & $\mathrm{CCC}$ & 5 & yes, liver & 6 & yes \\
\hline $\begin{array}{l}\text { Sosa-Durán } \\
\text { [30] }\end{array}$ & 2015 & 45 & NA & 8 & 9 & yes & $\mathrm{CCC}$ & 16 & no & NA & NA \\
\hline Ruiz [11] & 2015 & 41 & 20 & NA & 14.8 & yes & $\mathrm{CCC}$ & 6 & yes, local & NA & NA \\
\hline Ruiz [11] & 2015 & 57 & 30 & 9 & 19.4 & yes & $\mathrm{CCC}$ & NA & no & NA & NA \\
\hline Aust [31] & 2015 & 47 & 16 & 6 & 10 & yes & $\mathrm{CCC}$ & 10 & no & NA & NA \\
\hline Liu[32] & 2014 & 39 & 10 & 60 & 6 & yes & $\mathrm{CCC}$ & 10 & yes, local & 12 & yes \\
\hline Heller [33] & 2014 & 37 & 8 & 96 & 18 & yes & $\mathrm{CCC}$ & 5 & yes, & NA & NA \\
\hline Dobrosz [34] & 2014 & 42 & NA & 16 & NA & yes & $\mathrm{CCC}$ & NA & NA & NA & NA \\
\hline ljichi [35] & 2014 & 60 & 37 & 48 & 4 & yes & $\mathrm{CCC}$ & 8 & yes, local & 23 & no \\
\hline Shalin [36] & 2012 & 47 & NA & 10 & 3 & yes & CCC & 7 & no & NA & NA \\
\hline Sawazaki [17] & 2012 & 41 & 18 & NA & 4.8 & yes & $\mathrm{CCC}$ & 4 & no & NA & NA \\
\hline Mert [37] & 2012 & 42 & NA & NA & 17.8 & yes & $\mathrm{CCC}$ & 26 & no & NA & NA \\
\hline Mert [37] & 2012 & 51 & 8 & 12 & 7 & yes & $\mathrm{CCC}$ & 49 & no & NA & NA \\
\hline Li [38] & 2012 & 49 & 26 & 25 & 9 & yes & $\mathrm{CCC}$ & 8 & no & NA & NA \\
\hline Yan [21] & 2011 & 41 & 5 & 4 & 6.3 & yes & $\mathrm{CCC}$ & 24 & no & NA & NA \\
\hline Bourdel [39] & 2010 & 43 & 20 & 60 & 9 & yes & $\mathrm{CCC}$ & 6 & yes & 22 & yes \\
\hline Williams [40] & 2009 & 53 & 24 & 4 & 4.7 & yes & $\mathrm{CCC}$ & 3 & $\begin{array}{l}\text { yes, local, } \\
\text { InguinalLN, } \\
\text { lung }\end{array}$ & 11 & yes \\
\hline Matsuo [41] & 2009 & 37 & 10 & 5 & 14 & yes & $\mathrm{CCC}$ & 24 & yes, local & NA & NA \\
\hline
\end{tabular}




\begin{tabular}{|c|c|c|c|c|c|c|c|c|c|c|c|}
\hline \multirow[t]{2}{*}{ Author } & \multirow[t]{2}{*}{ Year } & \multirow[t]{2}{*}{ Age } & \multirow{2}{*}{$\begin{array}{l}\text { Delay from } \\
\text { first } \\
\text { gynecological } \\
\text { surgery(yr) }\end{array}$} & \multirow{2}{*}{$\begin{array}{l}\text { Onset of } \\
\text { symptoms(m) }\end{array}$} & \multirow{2}{*}{$\begin{array}{l}\text { Lump } \\
\text { size }(\mathrm{cm})\end{array}$} & \multirow[t]{2}{*}{ Surgery } & \multirow[t]{2}{*}{ Pathology } & \multicolumn{4}{|c|}{ Patient outcome } \\
\hline & & & & & & & & $\begin{array}{l}\text { Follow- } \\
\text { up } \\
\text { time } \\
\text { (m) }\end{array}$ & Relapse & $\begin{array}{l}\text { Follow- } \\
\text { up } \\
\text { time } \\
\text { (m) }\end{array}$ & Death \\
\hline Rust [42] & 2008 & 42 & NA & 24 & 4.9 & yes & $\mathrm{CCC}$ & NA & NA & NA & NA \\
\hline Barts [18] & 2008 & 38 & 13 & 151 & 11 & yes & $\mathrm{CCC}$ & 8 & yes & NA & NA \\
\hline Achach [43] & 2008 & 49 & 20 & NA & 8.5 & yes & $\mathrm{CCC}$ & 6 & $\begin{array}{l}\text { yes, } \\
\text { bladder } \\
\text { and pelvic } \\
\text { bone }\end{array}$ & NA & NA \\
\hline Razzouk [22] & 2007 & 46 & 26 & NA & 17 & yes & $\mathrm{CCC}+\mathrm{EC}$ & 3 & yes, liver & 6 & yes \\
\hline Harry [44] & 2007 & 55 & NA & 15 & 4 & yes & $\mathrm{CCC}$ & 18 & no & NA & NA \\
\hline Sergent [45] & 2006 & 45 & 25 & 17 & 20 & yes & $\mathrm{CCC}$ & NA & yes & 6 & yes \\
\hline Alberto [46] & 2006 & 38 & 11 & 6 & 6 & yes & $\mathrm{CCC}$ & NA & NA & NA & NA \\
\hline Ishida [47] & 2003 & 56 & 24 & 7 & 10 & yes & $\mathrm{CCC}$ & NA & $\begin{array}{l}\text { yes, lung, } \\
\text { bone and } \\
\text { brain }\end{array}$ & 48 & yes \\
\hline Park [48] & 1999 & 56 & 24 & NA & 5 & yes & $\mathrm{CCC}$ & NA & NA & NA & NA \\
\hline Miller [49] & 1998 & 38 & 9 & 8 & 4 & yes & $\mathrm{CCC}$ & 60 & no & NA & NA \\
\hline Hitti [50] & 1990 & 46 & 14 & NA & 6 & yes & $\mathrm{CCC}$ & 30 & no & NA & NA \\
\hline $\begin{array}{l}\text { Schnieber } \\
\text { Agner-Kolb } \\
\text { [51] }\end{array}$ & 1986 & 40 & 15 & 18 & NA & yes & $\mathrm{CCC}$ & NA & yes & 18 & yes \\
\hline our case & 2020 & 49 & 19 & 204 & 6.3 & yes & $\mathrm{CcC}$ & 1 & no & NA & NA \\
\hline
\end{tabular}




\begin{tabular}{|c|c|c|c|}
\hline & & $\mathbf{n}$ & Percentage \\
\hline \multirow[t]{4}{*}{ Age(yr) } & $46.5 \pm 4.9$ & & \\
\hline & $31-40$ & 7 & $15.22 \%$ \\
\hline & $41-50$ & 28 & $60.87 \%$ \\
\hline & $51-60$ & 10 & $21.74 \%$ \\
\hline \multirow[t]{4}{*}{ Previous gynecological surgery } & $1 \mathrm{C}$ & 20 & $44.44 \%$ \\
\hline & $2 \mathrm{C}$ & 15 & $33.33 \%$ \\
\hline & $3 C$ & 6 & $13.33 \%$ \\
\hline & other surgeries & 4 & $8.89 \%$ \\
\hline \multirow[t]{5}{*}{ Delay from fist gynecological surgery (yr) } & $17.9 \pm 6.6$ & & \\
\hline & $0-10$ & 7 & $20.59 \%$ \\
\hline & $11-20$ & 15 & $44.12 \%$ \\
\hline & $21-30$ & 10 & $29.41 \%$ \\
\hline & $31-40$ & 2 & $5.88 \%$ \\
\hline \multirow[t]{5}{*}{ Onset of symptoms(yr) } & $4.4 \pm 5.2$ & & \\
\hline & $0-1$ & 19 & $52.78 \%$ \\
\hline & $1-2$ & 6 & $16.67 \%$ \\
\hline & $2-10$ & 6 & $16.67 \%$ \\
\hline & $10-33$ & 5 & $13.89 \%$ \\
\hline Follow-up time (m) & $15.0 \pm 11.5(1-60)$ & & \\
\hline
\end{tabular}

As for tumor markers, CA 125 was detected in 24 cases before the operation. 14 cases were in the normal range $(0-35 \mathrm{U} / \mathrm{mL}), 10 \mathrm{cases}$ were higher than the normal range, and the highest was $3157.9 \mathrm{U} / \mathrm{mL}$ [10]. The preoperative detection of CEA,7 was in the normal range in 9 cases, above the normal range in 2 cases, up to $96.5 \mu \mathrm{g} / \mathrm{L}$ [11]. CA 199 was detected in 12 cases before treatment, and above the normal range in 4 cases, up to $222 \mu \mathrm{g} / \mathrm{L}$ [12]. (Table S1).

Previously, only 15 patients had a history of endometriosis (44 patients had available information) and 12 patients had no abdominal masses before diagnosis without any intermittent, periodic, or persistent pain. But all patients had palpable abdominal surgical scar masses with an average diameter of $10.0 \mathrm{~cm}$ (standard deviation $4.4 \mathrm{~cm}$ ), up to $25 \mathrm{~cm}$. The pathological results of the mass are shown in Table 3. The most common histological type is CCC, in 43 cases (95.6\%), followed by CCC with endometrioid carcinoma in 2 cases (4.4\%). Of these, only 22 cases ( $51.2 \%$ ) found coexisting endometriosis implants (Table 3). In these cases, additional samples for a thorough search for residual lesions of endometrial glands were not all successful. In 1925, Sampson [13] put forward the criteria for the diagnosis of malignant transformation of endometriosis: (a) benign and neoplastic endometrial tissue were shown in the tumor at the same time; (b) histology was compatible with the origin of the endometrium; (c) no other primary tumor sites were found. Besides, Scott proposed the fourth criterion in 1953 [14], that was, (d) the morphological manifestation of benign endometriosis adjacent to malignant tissue is a prerequisite for judging malignant tumors originating from endometriosis. In the current situation, the first three criteria of the reported cases have been met, but the fourth criteria may not be met, which may be the result of the complete replacement of normal tissue due to the proliferation of a large number of tumors. 
Table 3

Pathological characteristics of lumps.

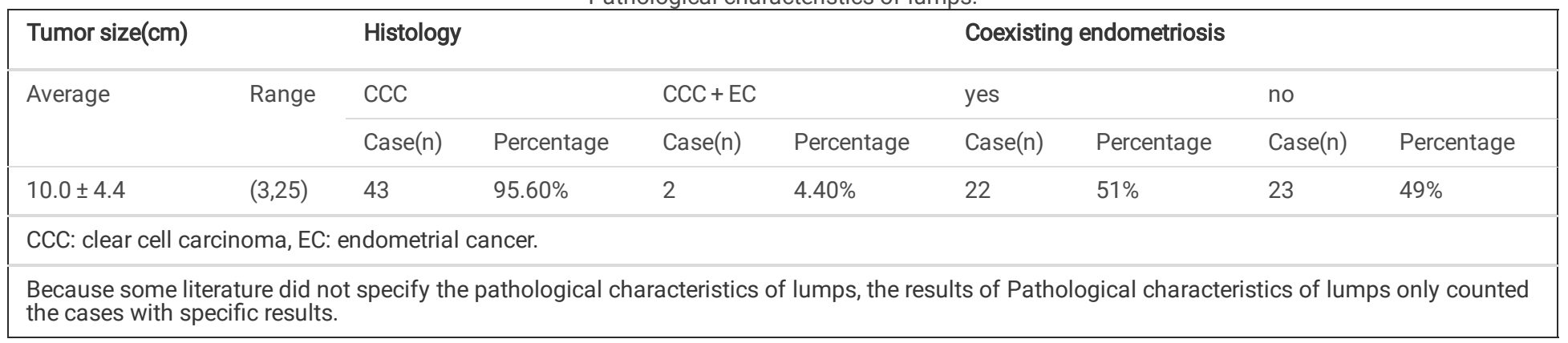

Also, we classified the tumor into large masses and small masses by $10 \mathrm{~cm}$ in diameter. The correlation between mass size and clinical features was shown in Table 4. The results suggested that patients with abdominal masses larger than $10 \mathrm{~cm}$ had more symptoms of abdominal pain before admission than those with small masses, and complained more about the pain caused by palpable masses $(P=0.015)$. There was no significant difference in other characteristics $(P>0.05)$.

Table 4

The correlation between mass size and clinical features.

\begin{tabular}{|c|c|c|c|}
\hline Clinical data & L-SE (8 cases) & S-SE ( 16 cases) & $\mathbf{P}$ \\
\hline Mean age (yr) (range) & $47.8(38-57)$ & $46.8(38-60)$ & NS \\
\hline No. of gynecological sugeries (range) & $1.3(1-3)$ & $1.5(1-3)$ & NS \\
\hline Delay from first surgery(y) & $14.8 \pm 7.7$ & $18.0 \pm 8.3$ & NS \\
\hline Onset of symptoms (m) & $66.5 \pm 74.9$ & $34.6 \pm 39.9$ & NS \\
\hline pain & 7 & 8 & 0.015 \\
\hline no pain & 1 & 8 & \\
\hline \multicolumn{4}{|c|}{ L-SE: Large scar endometrioma( $(10 \mathrm{~cm})$; S-SE: Small scar endometrioma; NS: Not significant. } \\
\hline \multicolumn{4}{|l|}{ NS: not significant. } \\
\hline
\end{tabular}

In terms of treatment, four patients received preoperative neoadjuvant chemotherapy (mainly platinum-based) [15-18], and one of them did not consider radical surgery because of the rapid progression of multiple metastases throughout the body [15]. Six patients were trying to treat vaginal estradiol medroxyprogesterone injection, leuprolide acetate, gestrinone, riptorelin, leiprim [10, 19-22], including our case, but the effect was not satisfactory. Surgery is the main treatment for the most of patients. The first-stage operation was performed based on extensive resection of the tumor and extensive abdominal tissue. Two cases were not treated surgically because of multiple metastases throughout the body and the rapid progression of the disease $[15,23]$. Due to the extent of the fascia defect, 22 patients $(47.8 \%)$ used mesh to reconstruct the abdominal wall (including our case]. Other regular operations include hysterectomy (27 cases, $60.0 \%$ ) and/or salpingectomy (29 cases, $64.4 \%$ ), and / or lymph node dissection ( 14 cases, $30.4 \%$ ) and/or omental resection (15 cases, $33.3 \%$ ). Although radical surgery is a major part of the treatment of all patients, our case did not performe hysterectomy and bilateral salpingo-oophorectomy plus pelvic lymphadenectomy, because no signs of the above organs were involved. Another reason is that we plan to perform postoperative radiotherapy for the patient after chemiotherapy. The follow-up adjuvant therapy is mainly chemotherapy, usually platinum and paclitaxel drugs. Twenty-nine cases (64.4\%) received 1-9 cycles of adjuvant chemotherapy. However, due to the poor individual characteristics and compliance, adverse reactions, or partial reactions to the treatment, the treatment is interrupted and the efficacy of chemotherapy is difficult to evaluate. Only 16 patients (34.8\%) received radiotherapy after surgery and chemotherapy (Table S1).

The above patients obtained the latest clinical follow-up information currently available, and eventually, 38 patients were able to know the outcome (Table S1). The follow-up time of the above patients ranged from 1 to 60 months, with an average of 15.0 months. 34.2\% of women (13/38) died between 5 and 48 months after diagnosis. As shown in the Kaplan-Meier survival curve (Fig. 7), the median survival time is 48 months and the five-year survival rate is $35 \%$. Seventeen patients were reported to relapse. The sites of recurrence were local ( 5 cases), lymphatic metastasis ( 3 cases, all inguinal lymph nodes) [15, 20, 24], distant metastasis (4 cases of liver, 2 cases of lung, 2 cases of brain, and 2 cases of bone). Univariate Cox regression model showed that the prognosis of patients with metastasis ( 17 cases, $17 / 37$, Of the 38 cases with a specific follow-up period, one death was excluded because it was not known whether there was metastasis.) was worse than that without metastasis (20 cases, $20 / 37)$, as shown by Kaplan-Meier curve (Fig. 8), suggesting that metastasis invasion is a poor prognostic factor affecting patient survival. This is consistent with Taburiaux's study [25].

At present, there is no multicenter RCT in the study of abdominal CCC. However, we can put forward some general directions for future treatment and research, and emphasize several findings that seem to appear from our data: (a) abdominal wall scar CCC appears in relatively young women and is an invasive disease with a poor prognosis, with a 5-year survival rate of about 35\%. (b) it is an iatrogenic disease of abdominal wall scar formation after 
gynecological surgery, and CS is the most common. (c) the progression of the disease was slow, and the average time of diagnosis was 17.9 years after the first gynecology and obstetrics operation. In this case, it often relapses to benign nodules of endometriosis, and sometimes patients undergo repeated surgery. (d) the size of the tumor was large at the time of diagnosis, and most of them needed extensive surgical repair of abdominal wall defects. (e) the use of progesterone or gonadotropin-releasing hormone analogs ( $\mathrm{GnRH}-\mathrm{a})$ before surgical treatment is limited to the number of cases, and the effects are not clear.

The limitation of the review lies in the rarity of the disease, resulting in data collection based only on case reports, with heterologous information from different specialties. This leads to a lack of useful data, which limits statistical analysis. Although we have carried out a lot of statistical analysis, no clear results have been obtained. However, the results of this analysis can guide us to better understand the CCC risk factors and optimal treatment of abdominal wall endometriosis.

\section{Conclusion}

The transformation of abdominal endometriosis to CCC is a rare and little-known complication, but invasive surgical resection with a safe margin in combination with lymph node dissection is still the most effective and survival treatment. The role of adjuvant therapy is still unclear, so further research is needed to assess the long-term benefits. Our case did not undergo radical hysterectomy and lymphadenectomy because there was no local, lymph node and distant metastasis, and planned follow-up radiotherapy and chemotherapy. Of course we need to long term and closely follow up to investigate if lymphatic metastasis and distant metastasis occurred, including liver, lung, brain and bone metastasis.

\section{Abbreviations}

CS: cesarean section; CCC: clear cell carcinoma; MRI: magnetic resonance imaging.

\section{Declarations}

\section{Acknowledgments}

Not applicable.

\section{Author Contributions}

Liang XZ and Zeng $\mathrm{H}$ wrote the first draft of the manuscript, Tang Z and Liao JJ participated in the patient's management; Liang XZ and Fan JT performed the literature review; Fan JT performed radiological diagnosis and supervised the patient's management, critically revised the paper and gave a scientific contribution.

\section{Funding}

Not applicable.

\section{Ethics approval and consent to participate}

Approval of the Ethics Committee of the First Affiliated Hospital of Guangxi Medical University was obtained for this study, and the patient signed informed consent form.

\section{Consent for publication}

The patient signed consent for publication.

\section{Availability of data and materials}

Data sharing is not applicable to this article as no datasets were generated.

\section{Competing interests}

The authors declare that they have no competing interests

\section{References}

1. Kocakusak A, Arpinar E, Arikan S, Demirbag N, Tarlaci A, Kabaca C: Abdominal wall endometriosis: a diagnostic dilemma for surgeons.Med Princ Pract 2005, 14:434-437.

2. Van Gorp T, Amant F, Neven P, Vergote I, Moerman P: Endometriosis and the development of malignant tumours of the pelvis. A review of literature.Best Pract Res Clin Obstet Gynaecol 2004, 18:349-371.

3. Nirula R, Greaney GC: Incisional endometriosis: an underappreciated diagnosis in general surgery.J Am Coll Surg 2000, 190:404-407. 
4. Leng J, Lang J, Guo L, Li H, Liu Z: Carcinosarcoma arising from atypical endometriosis in a cesarean section scar.Int J Gynecol Cancer 2006, 16:432-435.

5. Da Ines D, Bourdel N, Charpy C, Montoriol PF, Petitcolin V, Canis M, Garcier JM: Mixed endometrioid and serous carcinoma developing in abdominal wall endometriosis following Cesarean section.Acta Radio/ 2011, 52:587-590.

6. Fargas Fabregas F, Cusido Guimferrer M, Tresserra Casas F, Baulies Caballero S, Fabregas Xaurado R: Malignant transformation of abdominal wall endometriosis with lymph node metastasis: Case report and review of literature.Gynecol Oncol Case Rep 2014, 8:10-13.

7. Nezhat C, Vu M, Vang N, Ganjoo K, Karam A, Folkins A, Nezhat A, Nezhat F: Endometriosis Malignant Transformation Review: Rhabdomyosarcoma Arising From an Endometrioma.JSLS2019, 23.

8. Mihailovici A, Rottenstreich M, Kovel S, Wassermann I, Smorgick N, Vaknin Z: Endometriosis-associated malignant transformation in abdominal surgical scar: A PRISMA-compliant systematic review.Medicine (Baltimore) 2017, 96:e9136.

9. Francica G: Reliable clinical and sonographic findings in the diagnosis of abdominal wall endometriosis near cesarean section scar. World $\mathrm{J}$ Radiol 2012, 4:135-140.

10. Lopes A, Anton C, Slomovitz BM, Accardo de Mattos L, Marino Carvalho F: Clear cell carcinoma arising from abdominal wall endometrioma after cesarean section.Int J Gynecol Cancer 2019, 29:1332-1335.

11. Ruiz MP, Wallace DL, Connell MT: Transformation of Abdominal Wall Endometriosis to Clear Cell Carcinoma.Case Rep Obstet Gyneco/2015, 2015:123740.

12. Tsuruga T, Hirata T, Akiyama I, Matsumoto Y, Oda K, Fujii T, Osuga Y: Mixed endometrioid and clear cell carcinoma arising from laparoscopic trocar site endometriosis.J Obstet Gynaecol Res 2019, 45:1613-1618.

13. SAMPSON JA: ENDOMETRIAL CARCINOMA OF THE OVARY, ARISING IN ENDOMETRIAL TISSUE IN THAT ORGAN.Archives of SUrgery 1925, 10:172.

14. Scott RB: Malignant changes in endometriosis. Obstet Gynecol 1953, 2:283-289.

15. Giannella L, Serri M, Maccaroni E, J DIG, Carpini GD, Berardi R, Sopracordevole F, Ciavattini A: Endometriosis-associated Clear Cell Carcinoma of the Abdominal Wall After Caesarean Section: A Case Report and Review of the Literature.In Vivo 2020, 34:2147-2152.

16. Ferrandina G, Palluzzi E, Fanfani F, Gentileschi S, Valentini AL, Mattoli MV, Pennacchia I, Scambia G, Zannoni G: Endometriosis-associated clear cell carcinoma arising in caesarean section scar: a case report and review of the literature. World J Surg Oncol 2016, 14:300.

17. Sawazaki H, Goto H, Takao N, Taki Y, Takeuchi H: Clear cell adenocarcinoma arising from abdominal wall endometriosis mimicking urachal tumor.Urology 2012, 79:e84-85.

18. Bats AS, Zafrani Y, Pautier P, Duvillard P, Morice P: Malignant transformation of abdominal wall endometriosis to clear cell carcinoma: case report and review of the literature. Fertil Steril 2008, 90:1197 e1113-1196.

19. Rivera Rolon MDM, Allen D, Richardson G, Clement C: Abdominal Wall Clear Cell Carcinoma: Case Report of a Rare Event with Potential Diagnostic Difficulties.Case Rep Pathol 2019, 2019:1695734.

20. Behbehani S, Magtibay P, Chen L, Wasson M: Clear Cell Carcinoma of the Anterior Abdominal Wall Secondary to latrogenic Endometriosis.J Minim Invasive Gynecol 2020, 27:1230-1231.

21. Yan Y, Li L, Guo J, Zheng Y, Liu Q: Malignant transformation of an endometriotic lesion derived from an abdominal wall scar.Int J Gynaecol Obstet 2011, 115:202-203.

22. Razzouk K, Roman H, Chanavaz-Lacheray I, Scotte M, Verspyck E, Marpeau L: Mixed clear cell and endometrioid carcinoma arising in parietal endometriosis.Gynecol Obstet Invest 2007, 63:140-142.

23. Lai YL, Hsu HC, Kuo KT, Chen YL, Chen CA, Cheng WF: Clear Cell Carcinoma of the Abdominal Wall as a Rare Complication of General Obstetric and Gynecologic Surgeries: 15 Years of Experience at a Large Academic Institution.Int J Environ Res Public Health $2019,16$.

24. Wei CJ, Huang SH: Clear cell carcinoma arising from scar endometriosis: A case report and literature review.Ci Ji Yi Xue Za Zhi 2017, 29:55-58.

25. Taburiaux L, Pluchino N, Petignat P, Wenger JM: Endometriosis-Associated Abdominal Wall Cancer: A Poor Prognosis? Int J Gynecol Cancer 2015, 25:1633-1638.

26. Gentile JKA, Migliore R, Kistenmacker FJN, Oliveira MM, Garcia RB, Bin FC, Souza P, Assef JC: Malignant transformation of abdominal wall endometriosis to clear cell carcinoma: case report.Sao Paulo Med J 2018, 136:586-590.

27. Marques C, Silva TS, Dias MF: Clear cell carcinoma arising from abdominal wall endometriosis - Brief report and review of the literature.Gynecol Oncol Rep 2017, 20:78-80.

28. Kostrzeba E, Barczyk M, Wichtowski M, Garstecki R, Murawa D: Clear Cell Carcinoma of the abdominal wall.Pol Przegl Chir 2017, 89:40-43.

29. Graur F, Mois E, Elisei R, Furcea L, Dragota M, Zaharie T, Al Hajjar N: Malignant endometriosis of the abdominal wall.Ann Ital Chir 2017 , 6.

30. Sosa-Duran EE, Aboharp-Hasan Z, Mendoza-Morales RC, Garcia-Rodriguez FM, Jimenez-Villanueva X, Penavera-Hernandez JR: [Clear cell adenocarcinoma arising from abdominal wall endometriosis]. Cir Cir 2016, 84:245-249.

31. Aust S, Tiringer D, Grimm C, Stani J, Langer M: Therapy of a clear cell adenocarcinoma of unknown primary arising in the abdominal wall after cesarean section and after hysterectomy. Wien Klin Wochenschr 2015, 127:62-64. 
32. Liu H, Leng J, Lang J, Cui Q: Clear cell carcinoma arising from abdominal wall endometriosis: a unique case with bladder and lymph node metastasis. World J Surg Oncol 2014, 12:51.

33. Heller DS, Houck K, Lee ES, Granick MS: Clear cell adenocarcinoma of the abdominal wall: a case report.J Reprod Med 2014, 59:330-332.

34. Dobrosz Z, Palen P, Stojko R, Wlaszczuk P, Niesluchowska-Hoxha A, Piechuta-Kosmider I: Clear cell carcinoma derived from an endometriosis focus in a scar after a caesarean section-a case report and literature review.Ginekol Pol 2014, 85:792-795.

35. Ijichi S, Mori T, Suganuma I, Yamamoto T, Matsushima H, Ito F, Akiyama M, Kusuki I, Kitawaki J: Clear cell carcinoma arising from cesarean section scar endometriosis: case report and review of the literature.Case Rep Obstet Gynecol 2014, 2014:642483.

36. Shalin SC, Haws AL, Carter DG, Zarrin-Khameh N: Clear cell adenocarcinoma arising from endometriosis in abdominal wall cesarean section scar: a case report and review of the literature.J Cutan Pathol 2012, 39:1035-1041.

37. Mert I, Semaan A, Kim S, Ali-Fehmi R, Morris RT: Clear cell carcinoma arising in the abdominal wall: two case reports and literature review.Am J Obstet Gynecol 2012, 207:e7-9.

38. Li X, Yang J, Cao D, Lang J, Chen J, Shen K: Clear-cell carcinoma of the abdominal wall after cesarean delivery.Obstet Gynecol $2012,120: 445-448$.

39. Bourdel N, Durand M, Gimbergues P, Dauplat J, Canis M: Exclusive nodal recurrence after treatment of degenerated parietal endometriosis. Fertil Steril 2010, 93:2074 e2071-2076.

40. Williams C, Petignat P, Belisle A, Drouin P: Primary abdominal wall clear cell carcinoma: case report and review of literature.Anticancer Res 2009, 29:1591-1593.

41. Matsuo K, Alonsozana EL, Eno ML, Rosenshein NB, Im DD: Primary peritoneal clear cell adenocarcinoma arising in previous abdominal scar for endometriosis surgery.Arch Gynecol Obstet 2009, 280:637-641.

42. Rust MM, Susa J, Naylor R, Cavuoti D: Clear cell carcinoma in a background of endometriosis. Case report of a finding in a midline abdominal scar 5 years after a total abdominal hysterectomy.Acta Cytol 2008, 52:475-480.

43. Achach T, Rammeh S, Trabelsi A, Ltaief R, Ben Abdelkrim S, Mokni M, Korbi S: Clear cell adenocarcinoma arising from abdominal wall endometriosis.J Oncol 2008, 2008:478325.

44. Harry VN, Shanbhag S, Lyall M, Narayansingh GV, Parkin DE: Isolated clear cell adenocarcinoma in scar endometriosis mimicking an incisional hernia.Obstet Gynecol 2007, 110:469-471.

45. Sergent F, Baron M, Le Cornec JB, Scotte M, Mace P, Marpeau L: [Malignant transformation of abdominal wall endometriosis: a new case report].J Gynecol Obstet Biol Reprod (Paris) 2006, 35:186-190.

46. Alberto VO, Lynch M, Labbei FN, Jeffers M: Primary abdominal wall clear cell carcinoma arising in a Caesarean section scar endometriosis./r J Med Sci 2006, 175:69-71.

47. Ishida GM, Motoyama T, Watanabe T, Emura I: Clear cell carcinoma arising in a cesarean section scar. Report of a case with fine needle aspiration cytology.Acta Cytol 2003, 47:1095-1098.

48. Park SW, Hong SM, Wu HG, Ha SW: Clear cell carcinoma arising in a Cesarean section scar endometriosis: a case report.J Korean Med Sci 1999, 14:217-219.

49. Miller DM, Schouls JJ, Ehlen TG: Clear cell carcinoma arising in extragonadal endometriosis in a caesarean section scar during pregnancy.Gynecol Oncol 1998, 70:127-130.

50. Hitti IF, Glasberg SS, Lubicz S: Clear cell carcinoma arising in extraovarian endometriosis: report of three cases and review of the literature.Gynecol Oncol 1990, 39:314-320.

51. Schnieber D, Wagner-Kolb D: [Malignant transformation of extragenital endometriosis].Geburtshilfe Frauenheilkd 1986, 46:658-659.

\section{Figures}

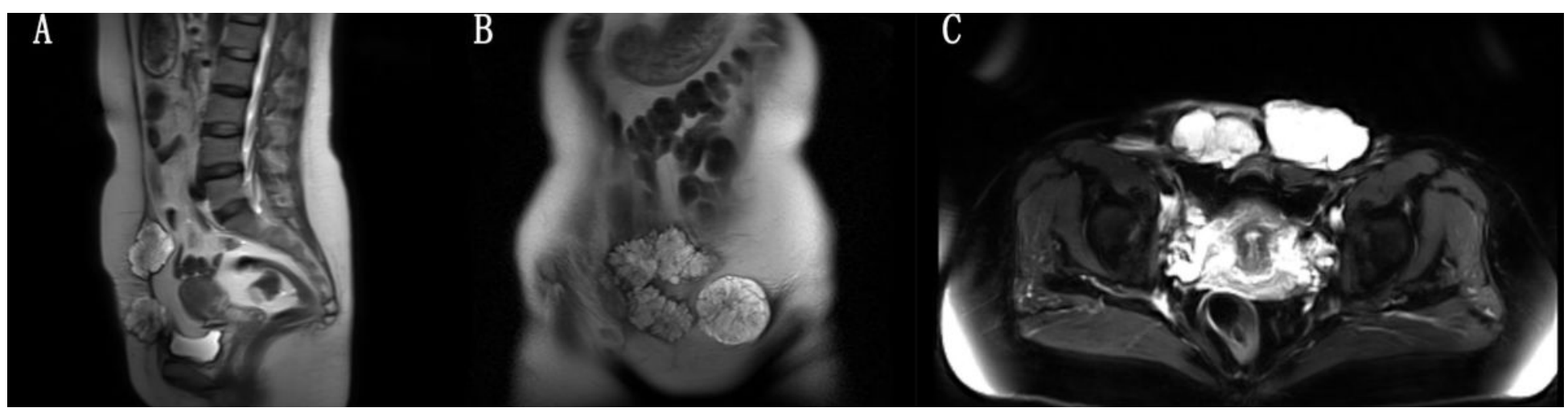

Figure 1 
CT image of the abdominal mass shows two lower rectus muscle heterogeneous lumps: (A) Sagittal view. (B) Coronal view. (C) Transverse view.

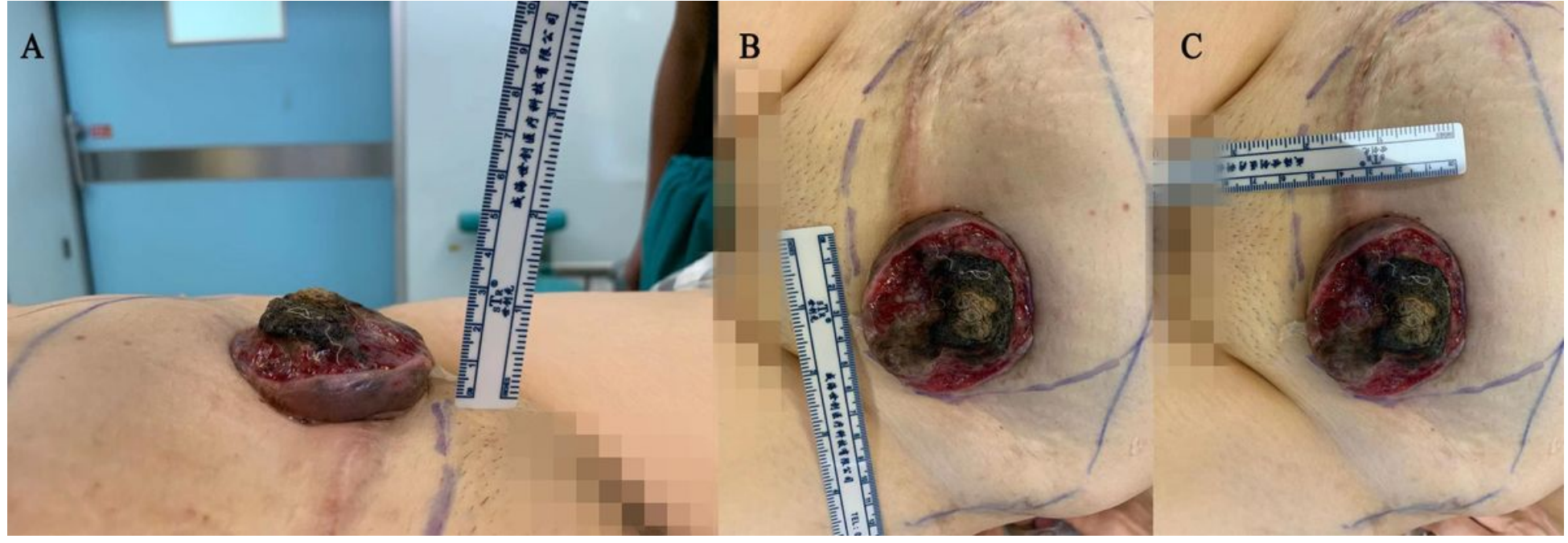

Figure 2

Photograph showing an ulcerated abdominal nodule associated with a cesarean section scar.

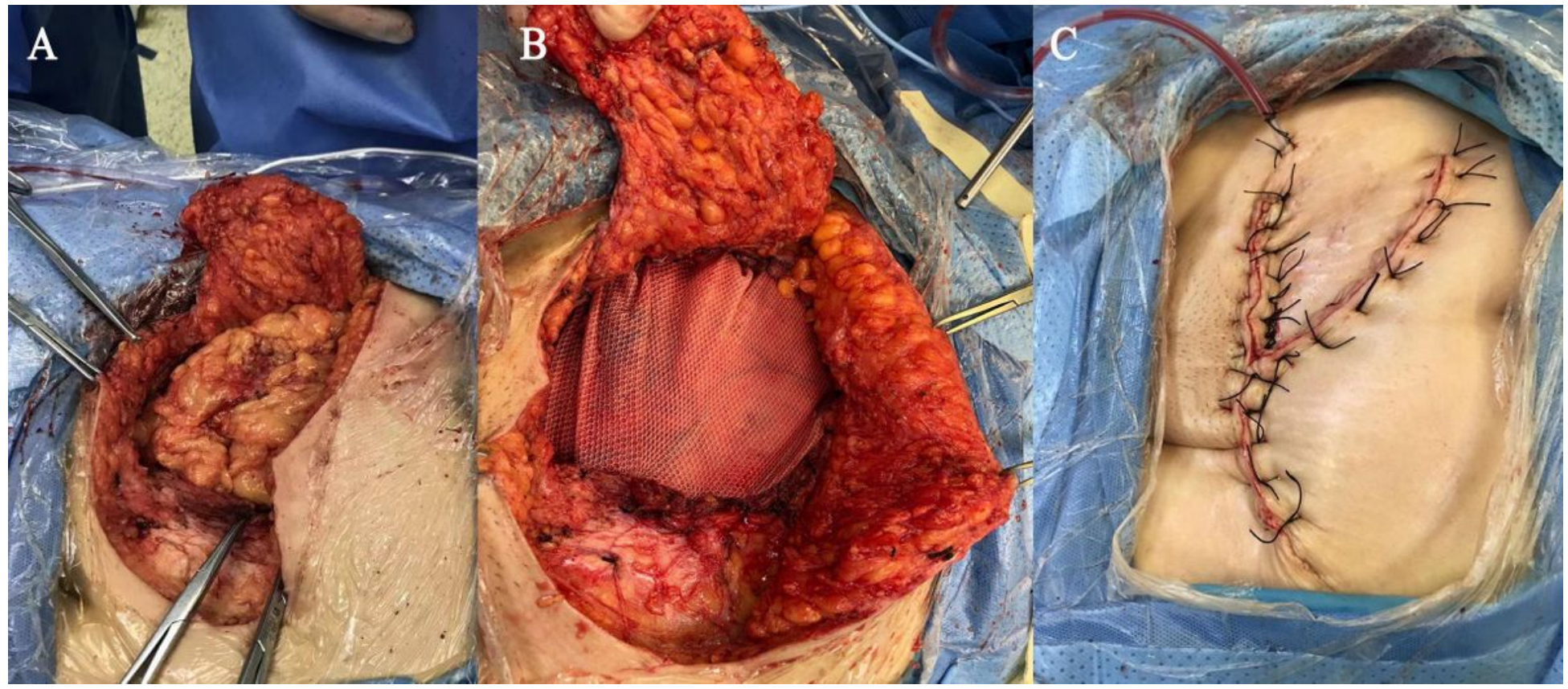

Figure 3

Photograph showing intraoperative tumor resection process. (A).Large defect of the abdominal wall after removal of the mass. (B).Placement of patch. (C).Surgical suture. 


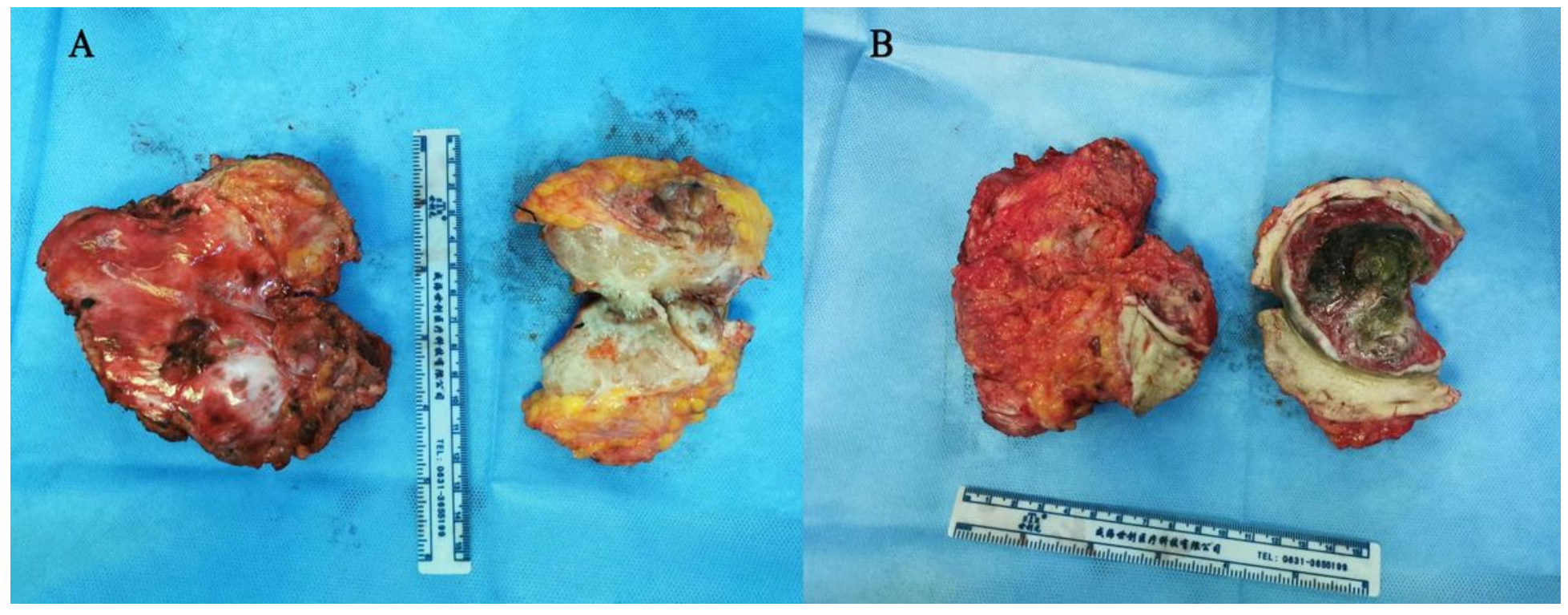

\section{Figure 4}

Macroscopic appearance demonstrating areas of cystic and solid components with brittle texture. (A).Gross appearance. (B). Internal components were shown after dissection.

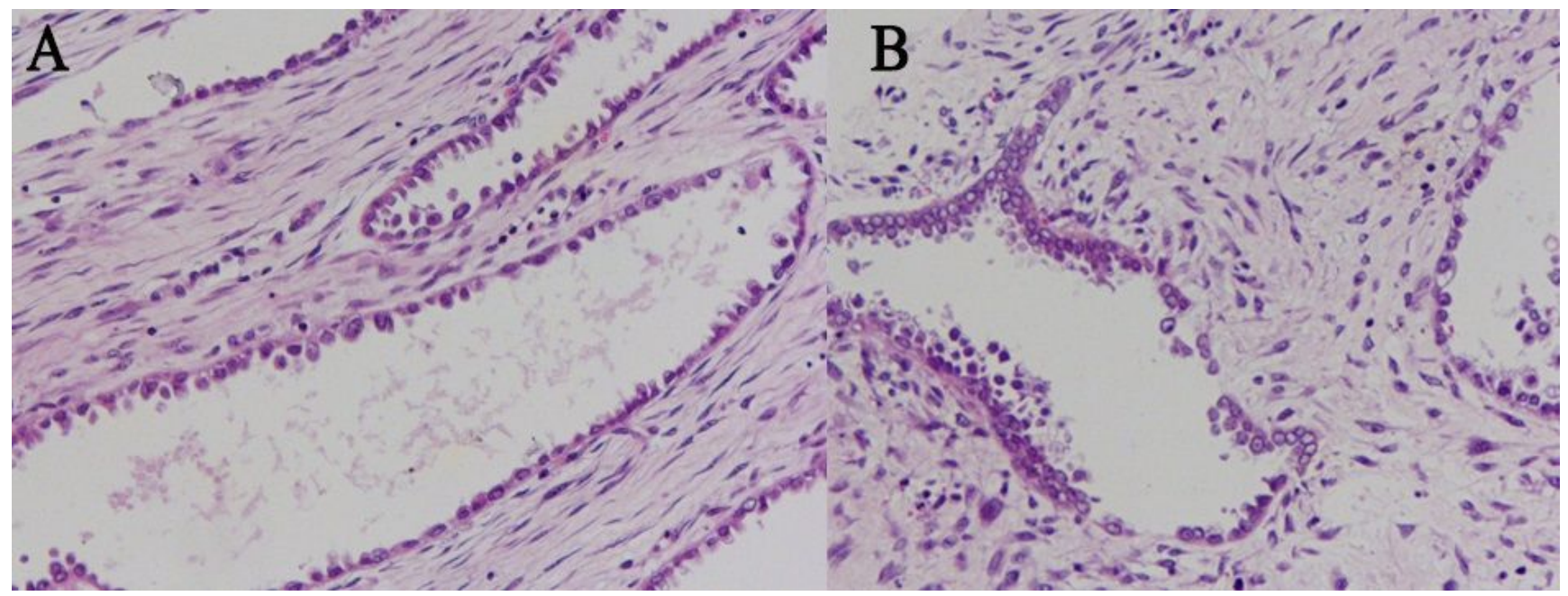

\section{Figure 5}

Histologic images of the tumor. (A). Higher magnification of cystic spaces lined by bland-appearing, flattened cells (H\&E stain, X200). (B). In other areas, the tumor shows irregular infiltrating glands with fibrous stroma. 


\section{Reported cases ( $n$ )}

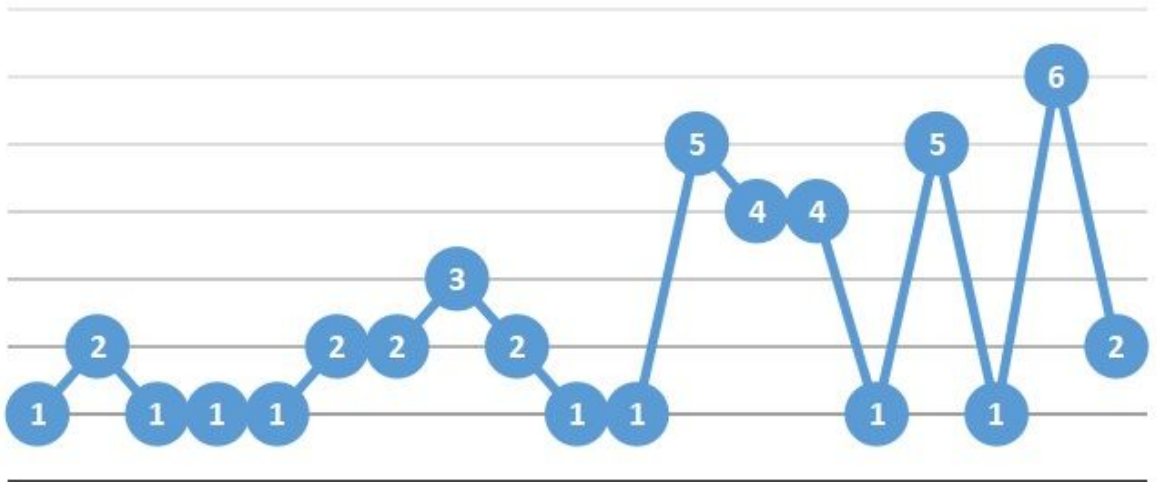

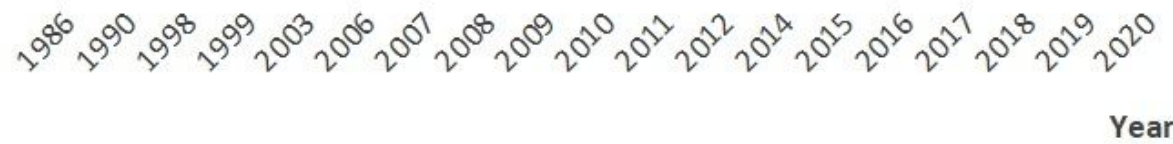

\section{Figure 6}

The year distribution of clear cell carcinoma caused by endometriosis in abdominal wall surgical wound has been reported.

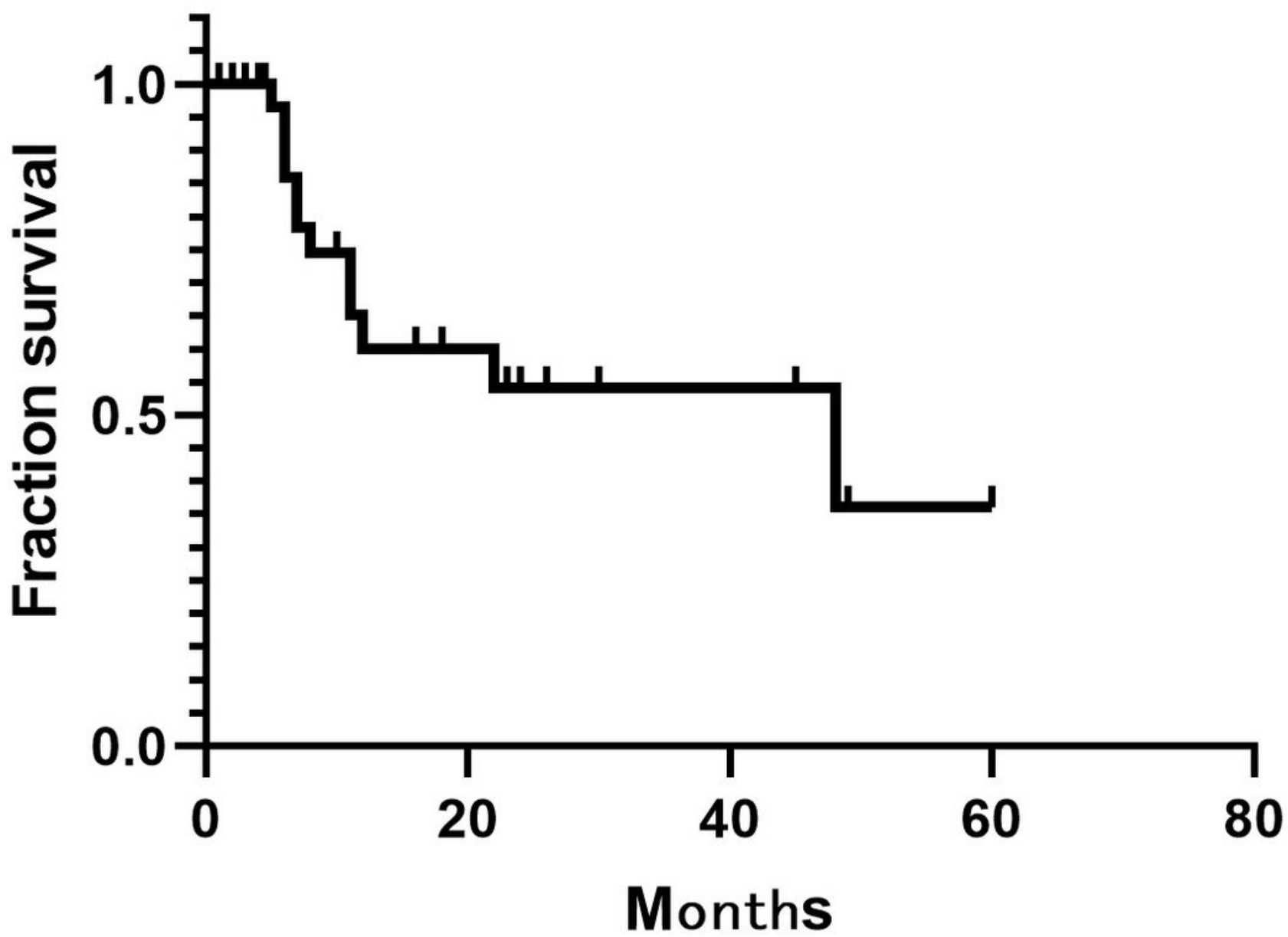


Kaplan-Meier curve for survival in patients with endometriosis-associated malignant transformation in abdominal surgical-scar showing high mortality up to 60 months following diagnosis. The median survival time is 48 months and the five-year survival rate is $35 \%$

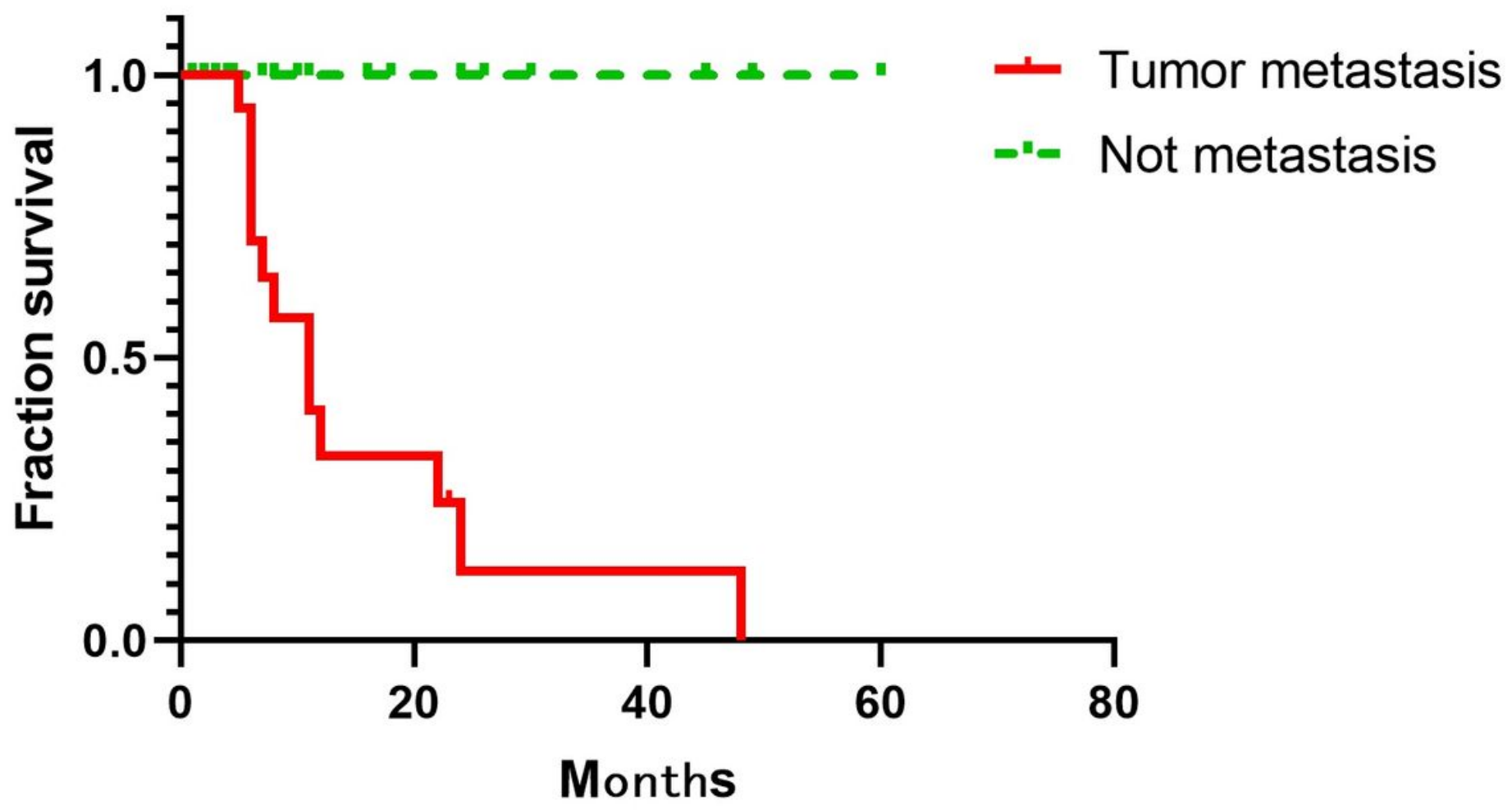

Figure 8

Kaplan-Meier curve for survival between patients with metastasis and without metastasis during the follow-up treatment.

\section{Supplementary Files}

This is a list of supplementary files associated with this preprint. Click to download.

- Tables1.xlsx 